\title{
Pengaruh Implementasi Pelatihan Terhadap Produktifitas Kerja Karyawan di PT. Exedy Manufacturing Indonesia
}

\author{
Ade Sofyan, Pupung Purnamasari², Dendin Jaenudin ${ }^{3}$ \\ 1,3 STMIK Kharisma Karawang, ${ }^{2}$ STIE Pertiwi Bekasi \\ Jalan Pangkal Perjuangan KM 1 (By Pass), Tanjungpura Karawang \\ *adesofyankharisma@gmail.com
}

\begin{abstract}
Abstrak- Penelitian ini, hanya mengkaji tentang pengaruh implementasi pelatihan terhadap produktivitas kerja karyawan bagian produksi di PT. EXEDY Manufacturing Indonesia yang masuk bekerja dari periode November 2017 sampai Januari 2018. Diperoleh persamaan regresi yang dapat digunakan untuk memprediksi variabel Produktivitas Kerja Karyawan melalui variabel Implementasi Pelatihan yaitu $Y=20,560+0,323 X$. Nilai a sebesar 20,560 memiliki makna bahwa apabila tidak ada implementasi pelatihan atau $x$ $=0$, maka produktivitas sebesar $=\mathbf{2 0 , 5 6 0}$. Dan apabila ada kenaikan atau peningkatan sebesar satu satuan, maka akan ada peningkatan sebesar 0,323. Diperoleh nilai $r$ sebesar 0,494 Maka dapat disimpulkan bahwa Implementasi Pelatihan memiliki pengaruh positif sedang terhadap Produktivitas Kerja Karyawan sebesar $r=\mathbf{0 , 4 9 4}$. Implementasi Pelatihan memiliki kontribusi $24,40 \%$ terhadap Produktivitas Kerja Karyawan PT. EXEDY Manufacturing Indonesia. Sedangkan sisanya yang sebesar 75,60 \% dipengaruhi oleh faktor lainnya.Terdapat pengaruh antara Implementasi Pelatihan terhadap Produktivitas Kerja Karyawan pada PT. EXEDY Manufacturing Indonesia karena nilai t hitung $(3,109)$ lebih besar daripada nilai t tabel $(2,037)$ sehingga H1 diterima serta nilai $t$ hitung terletak pada daerah penolakan $\mathrm{HO}$ artinya $\mathrm{H1}$ diterima. Itu artinya benar adanya bahwa terdapat pengaruh antara Implementasi Pelatihan terhadap Produktivitas Kerja Karyawan pada PT. EXEDY Manufacturing Indonesia.
\end{abstract}

Kata Kunci- Pelatihan, Produktivitas

\begin{abstract}
The present study examines the influence of training program on employee productivity at the production division of PT. Exedy Manufacturing Indonesia in the period of November 2017 to January 2018. The employee productivity is measured using the following regression equation: $Y=20.560+0.323 X$. The value of $Y$ of 20.560 means that without training program $(x=0)$, the employee productivity is 20.560. An increase of one unit means that there is an increase in productivity as much as 0.323 . The data analysis results in the $r$ value of 0.494, meaning that the training program has a positive effect on employee productivity as much as 0.494. The training program contributes to employee productivity as much as $24.40 \%$; the rest is influenced by factors other than the studied variable. It is also revealed that the observed $t$ is 3.109 , higher than the critical t of 2.037, meaning that the training program has an effect on employee productivity at PT. Exedy Manufacturing Indonesia.
\end{abstract}

Keyword: Training Program, Employee Productivity

\section{PENDAHULUAN}

Seiring berkembangnya ilmu dan pengetahuan yang makin maju maka perusahaan dituntut untuk lebih dapat menjadikan karyawannya lebih terampil dan terlatih dalam mengerjakan tugasnya. Seperti yang tercantum pada filosofi perusahaan yaitu menciptakan sukacita untuk pelanggan, masyarakat, serta karyawan dan untuk mewujudkankannya perusahaan berupaya mencapai zero defect terkhusus kepada karyawan yang bekerja di area pabrik.

Menurut kebijakan EXEDY yang tercantum pada buku pedoman perilaku EXEDY (2018:56) menyatakan bahwa "kami akan senantiasa menjalankan "'monozukuri,' dengan memperhatikan keselamatan dan menjaga kualitas yang sesuai dengan permintaan customer dalam rangka menyediakan produk dan layanan yang dapat digunakan oleh pelanggan dengan rasa puas. Serta melakukan challenge dengan berkelanjutan agar menjadi "perusahaan yang terbiasa dengan zero defect (NG 0)."

Namun pada tahun 2017 telah terjadi beberapa kasus ketidaksesuaian yang menyebabkan kerugian dan berpotensi mempengaruhi keberlangsungan perusahaan di masa berikutnya. Berikut adalah ketidaksesuaian yang terjadi pada tahun 2017 yang dipengaruhi oleh faktor manusia.

1) Inkonsistensi waktu implementasi pelatihan. Adakalanya waktu implementasi pelatihan mundur/bergeser dari waktu yang telah dijadwalkan. 2) Terjadi pergantian pelatih saat menjelang pelaksanaan pelatihan. Karena pelatih yang sesungguhnya berhalangan hadir, maka implementasi pelatihan digantikan oleh pelatih lainnya. 3) Peserta tidak fokus dalam pelatihan. Ada peserta yang tidak fokus dalam 
mengikuti pelaksanaan pelatihan. Seperti mengantuk, bercanda.

Menurut Siagian (2009 : 160) berikut adalah alasan mengapa pelatihan itu perlu dilaksanakan diantaranya :

1. Menurunnya produktivitas kerja. Kiranya perlu disadari bahwa merendahnya produktivitas kerja bisa terjadi karena masalah keperilakuan; akan tetapi mungkin juga karena keterampilan para tenaga pelaksana yang sudah tidak sesuai lagi. Untuk mengatasi kedua jenis penyebab tersebut, perlu pelatihan.

2. Jika para karyawan sering berbuat kesalahan dalam penyelesaian tugas pekerjaaannya, faktor-faktor penyebabnya juga mungkin karena perilaku yang disfungsional; akan tetapi mungkin pula karena menyangkut kemahiran menyelesaikan tugas.

3. Apabila karyawan ditempatkan pada tugas yang baru, juga diperlukan pelatihan.

4. Jika manajemen dan para karyawan sendiri merasa bahwa pengetahuan, kemahiran, dan keterampilan para karyawan sudah ketinggalan zaman."

Menurut Mulyadi (2016:127) bahwa "Untuk meningkatkan produktivitas kerja seseorang atau karyawan banyak sekali faktor yang mempengaruhi antara lain : tingkat pendidikan, kemampuan bekerja, skill atau keterampilan, etika kerja, mottivasi (dorongan), jaminan kesehatan, lingkungan kerja yang nyaman, sarana dan prasarana pendukung produksi, manajemen, disiplin, kerja, kompensasi, gaji atau upah." Sementara menurut Wibowo (2016:371) bahwa "Perubahan yang cepat dalam teknologi berlanjut menyebabkan meningkatnya tingkat keausan keterampilan. Agar tetap kompetitif, organisasi perlu melanjutkan pelatihan bagi sumber daya manusianya dalam menggunakan teknologi terbaik dan mutakhir yang tersedia. Merger dan akuisisi telah meningkat dengan pesat. Aktivitas ini mengintegrasikan sumber daya manusia dalam satu organisasi ke dalam organisasi lainnya yang mempunyai budaya sangat berbeda. Ketika hasil finansial dan kinerja dari aktivitas merger dan akuisisi lebih rendah dari rencana, biasanya alasannya adalah terletak pada sistem sumber daya manusia daripada sistem manajemen operasional atau finansial". Program pelatihan dianggap membawa manfaat yang cukup besar bagi perusahaan seperti meningkatkan moral karyawan, meningkatkan efisiensi waktu dalam melaksanakan pekerjaannya. Dari fenomena yang dikemukakan di atas, maka yang menjadi masalah pokok adalah seberapa besar pengaruh implementasi pelatihan terhadap produktivitas kerja karyawan di PT. EXEDY Manufacturing Indonesia.

\section{KAJIAN PUSTAKA}

\section{Pengertian Pelatihan}

Menurut Sikula dalam Mangkunegara (2015 : 44) bahwa : "Pelatihan (training) adalah suatu proses pendidikan jangka pendek yang mempergunakan prosedur sistematis dan terorganisir di mana pegawai non-managerial mempelajari pengetahuan dan keterampilan teknis dalam tujuan terbatas".

Menurut Mulyadi (2016 : 103) bahwa : "Pelatihan adalah merupakan salah satu proses untuk mengajarkan dan melatih pengalaman dan pengetahuan serta keahlian tertentu, sikap, etika, agar karyawan tersebut dapat melakukan tugas tanggung jawabnya semakin terampil dan baik sesuai dengan standar yang sudah ditentukan oleh organisasi”.

Pada dasarnya tujuan pelatihan yaitu ingin mengembangkan karyawan untuk terampil, terdidik, dan terlatih secara profesional dan siap pakai dalam bidangnya masing-masing. Dapat dikatakan bahwa ada beberapa komponen - komponen dalam pelatihan dan pengembangan. Menurut Anwar Prabu (2016 : 44) yaitu :

1. Tujuan dan sasaran pelatihan dan pengembangan harus jelas dan dapat diukur.

2. Para pelatih (trainers) harus memiliki kualifikasi yang memadai.

3. Materi pelatihan dan pengembangan harus disesuaiakan dengan tujuan yang hendak dicapai.

4. Metode pelatihan dan pengembangan harus sesuai dengan tingkat kemampuan pegawai yang menjadi peserta.

5. Peserta pelatihan dan pengembangan (trainee) harus memenuhi persyaratan yang ditentukan.

Pelatihan berhubungan dengan menambah pengetahuan keterampilan dan kecakapan untuk melakukan pekerjaan tertentu. Istilah pelatihan ini digunakan untuk menunjukkan setiap proses keterampilan atau kecakapan dan kemampuan para pegawai, sehingga mereka lebih baik menyesuaikan dengan lingkungan kerja yang mereka geluti.

Proses kegiatan pelatihan sering dilaksanakan oleh suatu perusahaan setelah terjadi penerimaan karyawan sebab latihan hanya diberikan pada karyawan dari perusahaan yang bersangkutan. Latihan adakalanya diberikan setelah karyawan tersebut ditempatkan dan ditugaskan sesuai dengan bidangnya masing-masing. Secara garis besarnya 
pelatihan merupakan suatu usaha untuk meningkatkan pengetahuan dan keterampilan serta kemampuan karyawan agar dapat melaksanakan suatu tugas atau pekerjaan yang dibebankan kepadanya secara efektif dan efisien.

\section{Produktivitas}

Peningkatan produktivitas merupakan masalah sistem dalam arti tertentu, karena ada banyak segi dari pekerjaan dan kegiatan perusahaan yang mempunyai dampak terhadap peningkatan produktivitas tenaga kerja. Bidang kerja yang dapat meningkatkan produktivitas di samping perlunya pembenahan kembali beberapa bagian organisasi dan fungsi staf untuk menunjang peningkatan produktivitas semaksimal mungkin.

Adanya konsep yang berbeda-beda tentang pengertian dari produktivitas, hal ini disebabkan karena belum adanya kesepakatan umum tentang pengertian produktivitas serta kriteria-kriteria yang jelas dalam mengukur petunjuk-petunjuk produktivitas. Tetapi secara umum produktivitas dapat diartikan sebagai suatu tingkat perbandingan antara besarnya keluaran dengan besarnya masukan. Pada dasarnya setiap bentuk masukan bila dikualifikasikan dapat digunakan sebagai faktor penyebut (pembagi) pada ukuran produktivitas. Atas itulah orang dapat berbicara tentang produktivitas seperti produktivitas lahan tenaga kerja atau berbagai produktivitas dari berbagai sub kategori lain dari masing-masing faktor produksi, dari pada kesempatan ini kita akan membahas tentang produktivitas tenaga kerja.

Menurut Encyclopedia Britanica (1982 : 27) dalam Sedarmayanti (2009 : 56) menjelaskan bahwa : "Produktivitas dalam ekonomi berarti rasio dari hasil yang dicapai dengan pengorbanan yang dikeluarkan untuk menghasilkan sesuatu ".

Produktivitas menurut Dewan Produktivitas Nasional mempunyai pengertian sebagai sikap mental yang selalu berpandangan bahwa mutu kehidupan hari ini harus lebih baik dari hari kemarin dan hari esok harus lebih baik dari hari ini. Memahami konsep dan teori produktivitas secara baik dapat dilakukan dengan cara membedakannya dari efektivitas dan efisiensi. Efektivitas dapat didefinisikan sebagai tingkat ketepatan dalam memilih atau menggunakan suatu metode untuk melakukan sesuatu (efektif $=$ do right tings). Efisiensi dapat diartikan sebagai tingkat ketepatan dan berbagai kemudahan dalam melakukan sesuatu (efisiensi $=$ do things right $)$.

Produktivitas memilki dua dimensi, dimensi pertama adalah efektifitas yang mengarah kepada pencapaian unjuk kerja yang maksimal yaitu pencapaian target yang berkaitan dengan kualitas, kuantitas, dan waktu, dan yang kedua yaitu efisiensi yang berkaitan dengan upaya membandingkan input dengan realisasi penggunaannya atau bagaimana pekerjaan tersebut dilaksanakan (Umar, 2004).

\section{Kerangka Pemikiran}

Kerangka berpikir secara sistematik dalam kajian ini dapat digambarkan sebagai berikut :

\begin{tabular}{|c|c|}
\hline $\begin{array}{l}\text { PELATIHAN } \\
\text { (X) }\end{array}$ & $\begin{array}{l}\text { PRODUKTIVITAS } \\
\text { (Y) }\end{array}$ \\
\hline $\begin{array}{l}\text { Sub variabel : } \\
\text { 1. Metode Pelatihan } \\
\text { 2. Materi Pelatihan } \\
\text { 3. Pelatih } \\
\text { Sumber: } \\
\text { Mangkunegara (2015:44) }\end{array}$ & $\begin{array}{l}\text { Sub variabel : } \\
\text { 1. Kemampuan \& } \\
\text { pengembangan diri } \\
\text { 2. Hasil pencapaian } \\
\text { 3. Semangat kerja } \\
\text { 4. Mutu } \\
\text { Sutrisno (2017:104) }\end{array}$ \\
\hline
\end{tabular}

Gambar 1. Kerangka Pemikiran

Dalam kaitannya dengan permasalahan yang telah dikemukakan sebelumnya, maka dikemukakan hipotesis penelitian bahwa melalui pelatihan karyawan akan dapat berpengaruh terhadap produktivitas kerja karyawan pada PT. EXEDY Manufacturing Indonesia.

\section{METODE PENELITIAN}

Berdasarkan latar belakang masalah pokok dan hipotesis yang dikemukakan sebelumnya, maka metode analisis yang digunakan untuk pengujian dan pembuktian hipotesis adalah analisis kuantitatif yaitu ; mengumpulkan data-data dan menyatakan variabelvariabel yang menggambarkan persepsi para karyawan/i terhadap pelaksanaan pelatihan dan kinerja mereka itu sendiri. Yang pada akhirnya akan menjadi total skor dari pengisian kuesioner responden. Pengisisan kuesioner menggunakan skala likert dengan ukuran interval. Skala likert adalah cara pengukuran dimana seorang responden diberikan pertanyaan dan kemudian memilih salah satu jawaban dari pilihan jawaban yang telah disediakan dengan bobot (skor) tertentu untuk setiap jawaban pertanyaan tersebut. Besarnya sampel dalam penelitian ini ditentukan menggunakan tabel isaac dan michael. Sampel yang dipilih adalah 32 karyawan/karyawati PT. EXEDY Manufacturing Indonesia bagian produksi yang masuk dari bulan November 2017 sampai dengan Januari 2018, dengan mengacu pada perhitungan sampel pada tabel Isaac dan Michael. Teknik pengambilan sampel yang digunakan penulis dalam penelitian ini adalah teknik sampling purposive. 


\section{HASIL DAN PEMBAHASAN}

Analisis Regresi Sederhana

Analisis regresi sederhana dilakukan sebagai berikut :

*) Mencari nilai b :

$\mathrm{b}=\frac{\mathrm{n} \sum \mathrm{XY}-\sum \mathrm{X} \sum \mathrm{Y}}{\mathrm{n} \sum \mathrm{X}^{2}-\left(\sum \mathrm{X}\right)^{2}}$

*) Mencari nilai a :

$\mathrm{a}=\frac{\sum \mathrm{Y}-\mathrm{b} \cdot \sum \mathrm{X}}{\mathrm{n}}$

Berdasarkan perhitungan di atas maka diperoleh persamaan regresi yang dapat digunakan untuk memprediksi variabel Produktivitas Kerja Karyawan melalui variabel Implementasi Pelatihan yaitu $\mathrm{Y}=20,560+0,323 \mathrm{X}$. Dari hasil perhitungan regresi tersebut diatas, terdapat nilai sebesar $\mathrm{a}=$ 20,560. Artinya apabila tidak ada implementasi pelatihan atau $\mathrm{x}=0$, maka produktivitas sebesar $=$ 20,560. Dan apabila ada kenaikan atau peningkatan sebesar satu satuan, maka akan ada peningkatan sebesar 0,323.

\section{Analisis Korelasi Sederhana}

Masih dengan menggunakan tabel tabel penolong di atas maka penulis dapat melakukan analisis korelasi sederhana sebagai berikut :

$r=\frac{n \sum X Y-\sum X \sum Y}{\sqrt{n \sum X^{2}-\left(\sum X\right)^{2}} \cdot \sqrt{n \sum Y^{2}-\left(\sum Y\right)^{2}}}$

Berdasarkan perhitungan di atas diperoleh nilai $r$ sebesar 0,494 Maka dapat disimpulkan bahwa Implementasi Pelatihan memiliki pengaruh positif terhadap Produktivitas Kerja Karyawan sebesar $\mathrm{r}=$ 0,494 . Korelasi Artinya jika terjadi peningkatan pada Implementasi Pelatihan maka akan meningkat pula Produktivitas Kerja Karyawan pada PT. EXEDY Manufacturing Indonesia. Sebaliknya, jika terjadi penurunan pada Implementasi Pelatihan maka akan menurun pula Produktivitas Kerja Karyawan pada PT. EXEDY Manufacturing Indonesia.

\section{Analisis Koefesien Determinasi}

$\mathrm{Kd}=\mathrm{r}^{2} .100 \%$

Berdasarkan perhitungan di atas maka dapat disimpulkan bahwa Implementasi Pelatihan memiliki kontribusi 24,40 \% terhadap Produktivitas Kerja Karyawan PT. EXEDY Manufacturing Indonesia. Sedangkan sisanya yang sebesar $75,60 \%$ dipengaruhi oleh faktor lainnya.

\section{Uji Signifikansi Koefesien Korelasi (Uji t)}

$$
t_{\text {hitung }}=\frac{2,705}{0,870}
$$

$t_{\text {hitung }}=3,109$

Setelah diperoleh nilai t hitung sebesar 3,109. Maka penulis perlu untuk mengetahui besarnya nilai $t$ tabel yang nantinya akan digunakan sebagai pembanding terhadap nilai t hitung. Nilai t hitung diperoleh dengan menggunakan taraf signifikansi $(\alpha)=$ 0,05 ; selanjutnya besarnya jumlah sampel dalam penelitian ini yaitu 32 responden, sehingga diperoleh nilai t tabel sebesar 2,037.

Berdasarkan nilai $t$ hitung dan nilai $t$ tabel di atas, maka penulis membuat grafik uji hipotesis dua pihak (two tailed) dengan tujuan mengetahui letak nilai t hitung, apakah terletak di daerah penolakan $\mathrm{H} 0$ atau terletak di daerah penerimaan $\mathrm{H} 0$.

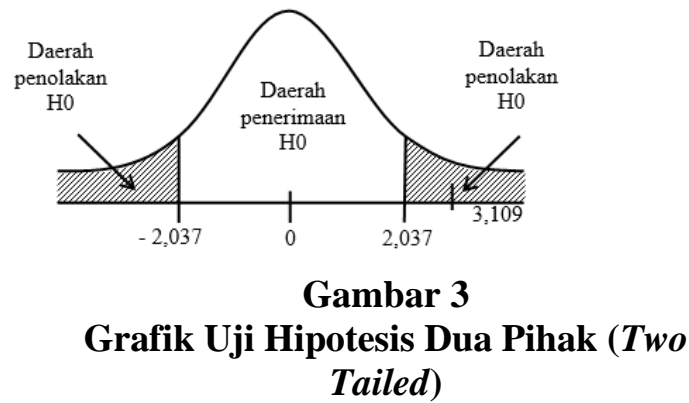

Berdasarkan kriteria yang digunakan pada metode uji signifikansi koefesien korelasi (Uji t) maka penulis menyimpulkan bahwa, terdapat pengaruh antara Implementasi Pelatihan terhadap Produktivitas Kerja Karyawan pada PT. EXEDY Manufacturing Indonesia karena nilai t hitung $(3,109)$ lebih besar daripada nilai $t$ tabel $(2,037)$ sehingga $\mathrm{H}_{1}$ diterima.

\section{Uji linearitas}

Uji linearitas bertujuan untuk mengetahui apakah dua variabel mempunyai hubungan yang linear atau tidak secara signifikan. Dasar pengambilan keputusan dalam uji linearitas adalah :

1. Jika nilai probabilitas $>0,05$, maka hubungan antara variabel implementasi pelatihan dengan produktivitas kerja karyawan adalah linear.

2. Jika nilai probabilitas $<0,05$, maka hubungan antara variabel implementasi pelatihan dengan produktivitas kerja karyawan adalah tidak linear.

\section{Analisa Hasil Penelitian}

Berdasarkan analisis data di atas maka dapat diperoleh bebearapa kesimpulan, antara lain :

1. Berdasarkan Analisis Deskriptif Variabel $X$ (Implementasi Pelatihan)

a. Implementasi Pelatihan yang terdapat pada PT. EXEDY Manufacturing Indonesia yaitu cukup baik. Hal ini ditunjukkan dengan nilai rata-rata dari total skor sebesar 43,28 yang 
terletak pada interval kelas 39,2 - 44,2 yaitu cukup baik.

b. Diperoleh pencapaian terbaik mengenai Implementasi Pelatihan pada soal nomor 10 karena mendapatkan nilai terbesar yaitu 133 . Pernyataan soal nomor 10 tersebut adalah "Pelatih memiliki kemampuan menyampaikan materi dengan baik" sehingga hal ini mengindikasikan kemampuan penyampaian materi pelatihan yang dimiliki pelatih dapat memperbaiki produktivitas kerja karyawan yang bekerja di perusahaan tersebut.

c. Diperoleh temuan masalah mengenai Implementasi Pelatihan pada soal nomor 7 karena mendapatkan nilai terendah yaitu 113 . Pernyataan soal nomor 7 tersebut adalah "Materi pelatihan dikemas dengan menarik dan efisien" sehingga hal ini mengindikasikan bahwa materi pelatihan bisa dikatakan belum dikemas secara efektif dan efisien.

2. Berdasarkan Analisis Deskriptif Variabel Y (Produktivitas Kerja Karyawan)

a. Produktivitas Kerja Karyawan yang terdapat pada PT. EXEDY Manufacturing Indonesia yaitu cukup baik. Hal ini ditunjukkan dengan nilai rata-rata dari total skor sebesar 34,53 terletak pada interval kelas 34,2 - 36,2 yaitu cukup baik.

b. Diperoleh pencapaian terbaik mengenai Produktivitas Kerja Karyawan pada soal nomor 4 karena mendapatkan nilai terbesar yaitu 143. Pernyataan soal nomor 4 tersebut adalah "Pekerjaan yang saya hasilkan sudah sesuai dengan target yang ditetapkan oleh perusahaan." Sehingga hal ini mengindikasikan bahwa hasil pekerjaan yang dilakukan dinilai telah sesuai dengan target yang ditentukan oleh perusahaan.

c. Diperoleh temuan masalah mengenai Produktivitas Kerja Karyawan pada soal nomor 1 karena mendapatkan nilai terendah yaitu 134. Pernyataan soal nomor 1 tersebut adalah "Saya selalu hadir setiap saat sesuai jadwal kerja untuk melaksanakan pekerjaannya" sehingga hal ini mengindikasikan bahwa karyawan tidak selalu hadir setiap saat sesuai jadwal kerja untuk melaksanakan pekerjaannya.

3. Berdasarkan analisis pengaruh Implementasi Pelatihan (X) terhadap Produktivitas Kerja Karyawan (Y). a. Diperoleh persamaan regresi yang dapat digunakan untuk memprediksi variabel Produktivitas Kerja Karyawan melalui variabel Implementasi Pelatihan yaitu $\mathrm{Y}=$ $20,560+0,323$ X. Nilai a sebesar 20,560 memiliki makna bahwa apabila tidak ada implementasi pelatihan atau $\mathrm{x}=0$, maka produktivitas sebesar $=20,560$. Dan apabila ada kenaikan atau peningkatan sebesar satu satuan, maka akan ada peningkatan sebesar 0,323 .

b. Diperoleh nilai $r$ sebesar 0,494 Maka dapat disimpulkan bahwa Implementasi Pelatihan memiliki pengaruh positif sedang terhadap Produktivitas Kerja Karyawan sebesar $\mathrm{r}=$ 0,494. Dalam hal ini dibuktikan pada tabel 3. Dalam hal ini dibuktikan pada tabel 3.2 yaitu Tabel Interpretasi Koefisien.

c. Implementasi Pelatihan memiliki kontribusi 24,40 \% terhadap Produktivitas Kerja Karyawan PT. EXEDY Manufacturing Indonesia. Sedangkan sisanya yang sebesar $75,60 \%$ dipengaruhi oleh faktor lainnya.

d. Terdapat pengaruh antara Implementasi Pelatihan terhadap Produktivitas Kerja Karyawan pada PT. EXEDY Manufacturing Indonesia karena nilai t hitung $(3,109)$ lebih besar daripada nilai $t$ tabel $(2,037)$ sehingga $\mathrm{H} 1$ diterima serta nilai t hitung terletak pada daerah penolakan $\mathrm{H} 0$ artinya $\mathrm{H} 1$ diterima. Itu artinya benar adanya bahwa terdapat pengaruh antara Implementasi Pelatihan terhadap Produktivitas Kerja Karyawan pada PT. EXEDY Manufacturing Indonesia.

\section{KESIMPULAN DAN SARAN}

Berdasarkan uraian dan penjelasan yang telah dikemukakan pada bab-bab sebelumnya, maka dapat ditarik kesimpulan dari penelitian ini yaitu sebagai berikut. Implementasi Pelatihan yang terdapat pada PT. EXEDY Manufacturing Indonesia yaitu cukup baik. Hal ini ditunjukkan dengan nilai rata-rata dari total skor sebesar 43,28 yang terletak pada interval kelas 39,2 - 44,2 yaitu cukup baik. Produktivitas Kerja Karyawan yang terdapat pada PT. EXEDY Manufacturing Indonesia yaitu cukup baik. Hal ini ditunjukkan dengan nilai rata-rata dari total skor sebesar 34,53 terletak pada interval kelas 34,2 - 36,2 yaitu cukup baik. Terdapat pengaruh antara Implementasi Pelatihan terhadap Produktivitas Kerja Karyawan pada PT. EXEDY Manufacturing Indonesia karena nilai t hitung $(3,109)$ lebih besar daripada nilai 
$\mathrm{t}$ tabel $(2,037)$ sehingga $\mathrm{H} 1$ diterima serta nilai t hitung terletak pada daerah penolakan $\mathrm{H} 0$ artinya $\mathrm{H} 1$ diterima. Implementasi Pelatihan memiliki pengaruh positif sedang $(r=0,494)$ seperti ditunjukkan pada tabel 3.2 (Tabel Interpretasi Koefisien Korelasi dan memiliki kontribusi 24,40 \% terhadap Produktivitas Kerja Karyawan PT. EXEDY Manufacturing Indonesia. Sedangkan sisanya yang sebesar 75,60\% dipengaruhi oleh faktor lainnya. Penulis juga memperoleh persamaan regresi yang dapat digunakan untuk memprediksi variabel Produktivitas Kerja Karyawan melalui variabel Implementasi Pelatihan yaitu $Y^{\prime}=20,560+0,322 X$. Nilai a sebesar 20,560 memiliki makna bahwa apabila tidak ada implementasi pelatihan atau $\mathrm{x}=0$, maka produktivitas sebesar $=$ 20,560. Dan apabila ada kenaikan atau peningkatan sebesar satu satuan, maka akan ada peningkatan sebesar 0,323.

Disarankan kepada perusahaan untuk tetap mengadakan pelatihan yang berkualitas agar produktivitas kerja karyawan dalam melaksanakan pekerjaan hasilnya akan lebih memuaskan pula. Hal ini harus didukung dengan metode pelatihan yang tepat, materi pelatihan yang relevan dengan praktek pekerjaan karyawan tersebut, serta didukung kemampuan instruktur pelatihan yang profesional dan berkompeten dalam pelaksanaan pelatihan tersebut. Produktivitas kerja karyawan masih belum mampu untuk beradaptasi dan bekerja sesuai apa yang telah ditugaskan kepada setiap karyawannya dengan job description tiap-tiap karyawan, Maka disarankan kepada perusahaan untuk melakukan pelatihan dan pengembangan karyawan mengenai SOP dan job description agar karyawan mempunyai nilai tambah baik skill-nya. Bagi peneliti selanjutnya mengingat masih ada faktor lain yang berkontribusi terhadap produktivitas kerja karyawan sebesar 75,60 \%, maka hal itu dapat dijadikan pertimbangan untuk penelitian selanjutnya agar lebih diketahui tentang faktor - faktor penting yang berkontribusi terhadap produktivitas kerja karyawan.

\section{REFERENSI}

[1] Darmadi, Hamid. 2010. Metode Penelitian Pendidikan. Bandung: Alfabeta.

[2] Dharma, Surya, Paradigma Baru : Manajemen Sumber Daya Manusia. Yogyakarta : Amara books., 2002
[3] Gary, dessler, Manajemen Sumber Daya Manusia. Jakarta ; indeks, 2009

[4] Hasibuan, Malayu. 2016. Manajemen Sumber Daya Manusia, Bumi Aksara, Jakarta.

[5] Hikmawati. F. 2017. Metodologi Penelitian. PT. Raja Grafindo Persada, Depok.

[6] Mulyadi. 2016. Pengantar Manajemen. IN Media, Bogor.

[7] Mangkunegara, A.P. 2015. Manajemen Sumber Daya Manusia, PT. Remaja Rosdakarya, Bandung.

[8] Nawawi, Hadari. 2008. Manajemen Sumber Daya Manusia: Untuk Bisnis yang Kompetitif. Yogyakarta: Gadjah Mada University Press.

[9] Ndraha, Taliziduhu. 2013. Pengantar Teori Pengembangan Sumber Daya Manusia. Jakarta: Rineka Cipta.

[10] Sugiyono. 2011. Metode Penelitian. Alfabeta, Bandung.

[11] Sedarmayanti. 2009. Manajemen Sumber Daya Manusia dan Produktivitas Kerja, CV. Mandar Maju, Bandung.

[12] Siagian S.P. 2009. Kiat Meningkatkan Produktivitas Kerja. PT. Rineka Cipta, Jakarta.

[13] Sutrisno. S. 2017. Manajemen Sumber Daya Manusia. Kencana, Jakarta.

[14] Sujarweni. V. Wiratna. 2015. Metodologi Penelitian Bisnis dan Ekonomi. Pustaka Baru Press, Yogyakarta.

[15] Usman. H. Dan Akbar P.S. 2017. Metode Penelitian Sosial. Bumi Aksara, Jakarta.

[16] Wibowo. 2016. Bisnis, Manajemen Kinerja, PT. Raja Grafindo Persada, Jakarta.

[17] Yuniarsih, Tjutju. 2009. Manajemen Sumber Daya Manusia. Bandung: Alfabeta. 